\title{
ACUTE TOXICITY OF SILVER NANOPARTICLES SYNTHESIZED FROM CISSUS QUADRANGULARIS IN POECILIA RETICULATA LARVAE AND ITS ANTIBIOFILM ACTIVITY AGAINST GRAM POSITIVE \& GRAM NEGATIVE BACTERIA Shanthi Sathappan 1, Vaseeharan Baskaralingam" \\ ${ }^{1}$ Institute of Animal Science,Poultry and Aquaculture Sci. Dept., Agricultural Research Organization, The Volcani Center, P.O.Box 6, Bet Dagan 50250, Israel. \\ ${ }^{2}$ Department of Animal and Health and Management, Alagappa University, Science Block $4^{\text {th }}$ Floor, Karaikudi-630004, Tamil Nadu, India. \\ *Corresponding author: Vaseeharanb@gmail.com
}

The biosynthesized silver nanoparticles using Cissus quadrangularis (CQ-AgNPs) showed excellent antibacterial activity against gram-positive (Bacillus licheniformis, Bacillus pumilus), and gram-negative bacteria (Pseudomonas aeruginosa, Vibrio parahaemolyticus). The maximum zone of inhibition was higher in Pseudomonas aeruginosa $(3 \mathrm{~mm}, 4 \mathrm{~mm}, 5 \mathrm{~mm}$, and $6 \mathrm{~mm}$, respectively) than other bacterias. The light and CLSM microscopic images showed strong adhering ability of gram-positive and gram-negative bacteria which led to the development of dense biofilm formation on the glass pieces. Moreover, treatment with CQAgNPs also affected the thickness $(\mu \mathrm{m})$ of the biovolume $(\mu \mathrm{m} 3)$ and the average thickness $(\mu \mathrm{m})$ was reduced in the biofilms formed by both bacteria's, as evidenced through COMSTAT analysis. The toxicity studies in Poecilia reticulata larvae showed 100\% mortality in AgNO3 $(1 \mu \mathrm{g} / \mathrm{ml}) ; 40 \%$ in CQ-AgNPs $(20 \mu \mathrm{g} / \mathrm{ml})$ whereas no mortality was observed for the CQ extract up to $500 \mu \mathrm{g} / \mathrm{ml}$. Histopathological observation showed that the abnormal tissue texture in CQAgNPs treated Poecilia reticulata larvae. Further, the CQ-AgNPs treated Poecilia reticulata larvae cells showed DNA damage at the concentration of $20 \mu \mathrm{g} / \mathrm{ml}$ in the $0.6 \%$ agarose gel when compare to the control. The protein released from the CQ-AgNPs treated Poecilia reticulata larvae cells were disrupted quickly with sodium dodecyl sulphate (SDS) than the non-treated cells and shown the protein profile ranging from $118 \mathrm{KDa}$ to135 KDa. Hence, the current findings suggest that CQ-AgNPs would appear to have a less toxic effect than $\mathrm{AgNO}_{3}$ on aquatic organisms in freshwater environments especially in Poecilia reticulate; thus more attention should be paid to preventing their accidental or intentional release into aquatic ecosystems.

Keywords: Acute toxicity, AgNPs, Poecilia reticulate, Biofilm, Cissus quadrangularis *Corresponding author: Vaseeharanb@gmail.com 